Egyptian Journal of Aquatic Biology \& Fisheries

Zoology Department, Faculty of Science,

Ain Shams University, Cairo, Egypt.

ISSN $1110-6131$

Vol. 25(3): 435 - 459 (2021)

www.ejabf.journals.ekb.eg

\title{
Evaluation of the effect of some chemicals used in the Nile tilapia (Oreochromis niloticus) culture
}

\author{
Abdel-Maguid, Wafaa Fadil ${ }^{1}$; Hassan, Azza $^{2}$; Zaki, Viola ${ }^{3}$ \\ ${ }^{1}$ Fish Dept. Animal Health Research Institute, Mansoura, Egypt. \\ ${ }^{2}$ Biochemistry Dept. Animal Health Research Institute, Mansoura, Egypt. \\ ${ }^{3}$ Dept. of Internal Medicine, infectious \& fish Diseases, Fac. Vet. Med., Mansoura Univ., Egypt.
}

"Corresponding Author: tofa.elsayed@yahoo.com

\section{ARTICLE INFO}

Article History:

Received: May 3, 2021

Accepted: June 5, 2021

Online: June 9, 2021

\section{Keywords:}

Oreochromis niloticus, oxytetracycline, malathion, qPCR,

DNA damage, histopathological alterations.

\section{ABSTRACT}

This study was conducted to assess genotoxic and histopathological changes induced by some chemicals applied in aquaculture as Oxytetracycline (OTC) from antibiotics group, Malathion (MAL) from pesticides group, or Formalin and malachite green FMG from disinfectants group in Nile tilapia (Oreochromis niloticus) culture as a model of toxicological studies in aquatic surroundings. Fish were exposed to OTC in a dose of $80 \mathrm{mg} / \mathrm{kg} / \mathrm{biomass} / \mathrm{day}, \mathrm{MAL}$ in a dose of $0.1 \mathrm{ppm}$, or FMG in a dose of $100 \mathrm{ppm}$ and $0.2 \mathrm{ppm}$ respectively for 21 days. The genotoxic effect was determined through DNA damage detection by comet assay as revealed a significant increase in tail length, tail DNA\%, and tail moment, all chemicals revealed DNA damage when compared to control. qPCR revealed significant $(\mathrm{p}<0.05)$ down regulation of immunity-related genes, MHC IIA, Tlr7, and IgM heavy chain in head-kidney and significant $(\mathrm{p}<0.05)$ upregulation in the expression level of the inflammatory gene, TNF- $\alpha$, in liver tissue of all chemicals treated groups in comparison with a control group. Histopathological examination of liver and kidney revealed hepatocyte and renal damage.

\section{INTRODUCTION}

Fish has long been providing food or animal protein for millions of people to meet the increasing domestic and foreign demand for fish and fishery product, aquaculture has expanded and now become a booming industry around the world and it is expected to remain one of the most important rising animal food-producing sectors in terms of food nutrition, jobs, and foreign exchange earnings in any country economy (FAO, 2012). Global aquaculture production has doubled over the past decades, now accounting for $50 \%$ of fishery products for human consumption according to a report by the Food and Agriculture Organization (FAO, 2014). China produces 41.1 million tonnes of farmed aquaculture products in 2012 , contributing to approximately $61.7 \%$ of total world output, as the main 
supplier of aquaculture products (Liu et al., 2017). Egypt aquaculture industry has grown at a faster rate than the world population growth over the last five decades (Salih $\boldsymbol{e t}$ al., 2017). Semi-intensive and extensive aquaculture are giving way to intensive aquaculture (FAO, 2010). Level of production reach to 200 tonnes/ hectare/year in intensive aquaculture systems as it can produce very high densities of fish, up to $200 \mathrm{~kg}$ per $\mathrm{m}^{3}$ of water (Shaalan et al., 2018). Feeding twice a day or constantly during daylight hours, resulting in a massive nutrient load (Rosa et al., 2020).

Nile tilapia (O. niloticus), is an important freshwater fish species. It is one of the most cultivated species worldwide under a wide range of geographic, climatic, and technological conditions (Van Doan et al., 2019), its tolerance to consuming a wide variety to natural food organisms to various environmental factors such as low water quality and diet types (Shaheen et al., 2013; Zulfiqar et al., 2020), It is considered the main cultivated and the most consumable fish in Egypt (Ahmed et al., 2021), that contributes with about $65.15 \%$ of Egyptian fish production (Gafrd, 2017).

Fish commonly used as an animal model in toxicology studies, since fish occupy the top of the aquatic food chain, they are commonly used as a bio-indicator for assessing aquatic ecosystem health (Burgos-Aceves et al., 2018), where the tilapia species is subjected to environmental stressors and rearing water toxicity (Abdel-Daim et al., 2019; Dawood et al., 2020).

Expansion usage of chemicals and drugs have been increased for many years as a part of management either to prevent or to treat diseases (Dogan $\boldsymbol{e t}$ al., 2020). It is reported that in commercial farming in the country the farmers exercise high stocking density, which subsequently necessitates larger use of fertilizers and supplementary feed references. Thus, the water quality and aquatic environment of the farms are deteriorated, which makes the fish/shrimp more susceptible to diseases. The disease outbreak in aquaculture occasionally leads to mass mortalities and economic losses references.

Therefore, the farmers/entrepreneurs indiscriminately use chemotherapeutics, feed additives, growth enhancers, etc. in aquaculture to increase fish/shrimp production and to combat diseases. For health control, the following are some of the commercial chemical products and medications currently used in aquatic life: Antibiotics (Tetracycline, Teramycene, Nitrofuran, Chloramphenicol, and others), methylene blue, sodium chloride, formalin, malachite green, potassium permanganate and glutaraldehyde (DOF, 2002).

Among pharmaceuticals, antibiotics (antibacterial or antimicrobials agents) are one of the most widely used groups, for human and veterinary uses having livestock and aquaculture growth promotion and prophylaxis (Yi et al., 2019). They are extensively used in aquaculture where they may be applied directly into the 
water or be incorporated in the food (Sharma, 2021). Owing to its higher effectiveness and lower cost as compared to other antibiotics, OTC is one of the most widely used antibiotics in fish farms (Ren et al., 2017).

Pesticides are chemical compounds or a mixture of substances used in agricultural crops controlling a wide range of insectivorous and herbivorous pests used for repelling, preventing, destroying, mitigating or that would otherwise reduce food production quantity and quality (Abd El-satar et al., 2019), MAL is a nonsystemic, wide-spectrum organophosphorus insecticide. MAL is commonly used in agriculture. Aquatic organisms, particularly fish, are highly sensitive to MAL (Uikey, 2015).

Disinfectant are chemical mixtures that eliminate many or all undesirable microorganisms (Stephen \& Hanne, 2013). Formaldehyde (formalin) is a chemical compound $(\mathrm{CHO})$ that can be applied basically as an outside parasiticide on fish and fish eggs as indefinite treatment for parasite control (Leal et al., 2018). Nowadays, the Food and Drug Administration (FDA) has approved and recommended three commercial products with formalin as an active principle for use in aquaculture, especially for the eradication of monogenean infestations (i.e. Gyrodactylus spp., Dactylogyrus spp., Cleidodiscus spp.) (Nasser et al., 2017).

Malachite green seems to be an organic pigment that has long been used as a fish fungicide and parasiticide. Instead of building out structures, it is mainly used inside cultivation services. Because of the persistent residues, a long withdrawal period is required after submission (Sudova et al., 2007). FMG can be used independently for treatment, but during treatment, they are usually used together because of the synergistic effect. They are more successful when they work together than when they work separately.

The present investigation has been carried out to determine the sub-chronic toxicity of OTC, MAL or FMG to assess the dangerous effect on the health of Nile tilapia, $O$. niloticus.

\section{MATERIALS AND METHODS}

\subsection{Chemicals}

\subsubsection{Oxytetracycline}

The commercial form of OTC $\left(\right.$ Terramycin $^{\circledR}$ ) used in the experiments was obtained from Pfizer (New York, New York, United States).

\subsubsection{Malathion}

The insecticide used in this study was 5\% (Powder form) emulsifiable concentrate of MAL (O, O dimethyl S-1,2 dicarbo-ethyl-thiophosphate) with molecular weight 330.35, was purchased from a local retail pesticides shop.

\subsubsection{Formalin}


37\% formaldehyde (El- Nasr Pharmaceutical Chemical Co., Egypt).

\subsubsection{Malachite Green}

(Deisenhofer, Germany: Sigma). The dose was determined using the treatment concentration $(0.20 \mathrm{mg} \mathrm{L} 1)$ of fish exposed to malachite green for a longterm bath ( $1 / 4$ or $1 / 5$ of the LC50 value).

\subsection{Test organisms}

A total number of one hundred and twenty (120) apparently healthy Nile tilapia, O. niloticus were collected from a private fish farm in Al-Manzala, AlDakahlia Governorate, Egypt. The fishes' weight and length ranged from $50 \pm 5 \mathrm{~g}$ and $15 \pm 1 \mathrm{~cm}$, respectively were used and transported in large plastic water containers to Animal Health Research Institute (AHRI), Fish disease and management Lab., Mansoura branch.

The fish were maintained in fully prepared glass aquaria $(80 \times 35 \times 40 \mathrm{~cm})$ filled with approximately 80 liters of dechlorinated tap water and left without any treatment for two weeks for acclimation before starting the experiment. Fish were kept in standard condition during the period of acclimation and the experiment in which provided with adequate aeration, 12:12hour light-to-dark photoperiod and underwater internal power filter keep at temperature $24 \pm 0.5 \circ \mathrm{C}$. Using digital $\mathrm{pH}$ meter where $\mathrm{pH}$ is $7.6 \pm 0.4$ and dissolved oxygen $(5.4 \pm 0.4 \mathrm{mg} / \mathrm{L})$. During the experiment, the fish were fed with commercial pellets purchased from same farm containing $30 \%$ crude protein at $3 \%$ of body weight twice a day, and during the acclimation period and experimental phase the aquaria were siphoned off daily for avoiding stress to the fish. Dead fish were removed as quickly as possible to maintain water quality.

\subsection{Experimental design and treatment}

One hundred and twenty (120) freshwater Nile tilapia were divided into four groups (30 fish each), fish were randomly assigned in two replicates into 4 groups of 15 fish / replicate. The experimental period lasted 21 days. One of the following treatments was offered to each group:

Group 1 (G1): Fish were reared in dechlorinated tap water free from any chemicals and fed a basal diet (30\% crude protein) considered as a Control group.

Group 2 (G2): Fish were fed the basal diet supplemented with OTC at (80 $\mathrm{mg} / \mathrm{kg} /$ biomass/day) (Julinta et al., 2019), antibiotics were coated with the fish diet by dissolving the antibiotics in liquid form on diet oil as a coating agent, mixing them and spray for fish diet. Next, let the fish diet containing antibiotics dry before administration.

Group 3 (G3): Fish were exposed to $1 / 4 \mathrm{LC}_{50}(0.1 \mathrm{ppm})$ of MAL 5\% (powder form) in water and fed on a basal diet (30\% crude protein). $1 \mathrm{mg}$ of MAL was dissolved in $1 \mathrm{ml}$ of distilled water to prepare a stock solution and then it 
diluted to determine the test final concentration $0.1 \mathrm{mg} / \mathrm{L}$ (Ibrahim, 2019) of MAL in the tanks.

Group 4 (G4): Fish were exposed to Formalin 37\% and Malachite green in the ratio (100 ppm (Andem et al., 2015), $0.2 \mathrm{ppm}$ (Sudova et al., 2007) respectively in water and fed on the basal diet (30\% crude protein).

The fish of all groups were fed $3 \%$ of their body weight two times daily for 21 days. The half amount of the water was changed daily to avoid the accumulation of fecal matter during acclimatization period. And after the start of the experiment, the water and chemicals were completely replenished day after day for 21 days of the experiment to maintain the toxicant concentration. Water quality parameters were monitored throughout the test.

\subsection{Tissue sample collection and preparation}

liver and kidney were collected. Liver was divided into three slices: the first one was kept in sterile Eppendorf tube, and then kept in $-20{ }^{\circ} \mathrm{C}$ for determination of gene expression (Real-time PCR), the second part (0.5g) was homogenized in 4.5 $\mathrm{ml}$ ice-cold phosphate buffer saline (Oxoid) at PH 7.4 (Sigma, UK). Liver homogenate in sterile plastic tubes was stored in $-20{ }^{\circ} \mathrm{C}$ was used for comet assay analysis and the third part of liver and kidney samples were stored in $10 \%$ formalin for histopathological analysis (mainly most affected whole liver and kidney tissue). Kidney sample was taken for gene expression and histopathological analysis.

Water samples were taken at the start and endpoint of the experiment for measuring of physical and chemical properties of it.

\subsection{Genotoxicity (DNA damage detection)}

The Comet assay (single cell gel electrophoresis, SCGE) was used to detect any potential DNA damage after various treatments. It investigates alkali labile sites and DNA strand breaks by measuring the migration of DNA from immobilized nuclear DNA. In the current study, the comet assay was conducted according to (Singh $\boldsymbol{e t} \boldsymbol{a l} ., \mathbf{1 9 8 8})$ and the calculations were done as previously described (Badawy et al., 2018).

\subsection{Molecular investigations (RNA Extraction, Synthesis of cDNA, and Real- time quantitative PCR (RT-qPCR))}

RT-qPCR was used to analyze gene expression, RNA was extracted from head kidney and liver tissues according to constructor's instructions, using the total RNA Purification Kit (Thermo Scientific, Fermentas, \# K0731), quantification of the resulting RNA was done using Nanodrop, to ensure that the levels were pure enough just to perform real-time PCR. Use (Uv-Vis spectrophotometer Q5000/USA) to measure the sum of nucleic acids the absorption of Ultra-Violet light with OD at 260/280 $\mathrm{nm}$ by purines and pyrimidines ring structure can be used. To convert RNA into complementary DNA (cDNA), $5 \mu \mathrm{g}$ of template RNA was 
reverse transcribed using Revert Aid $^{\mathrm{TM}} \mathrm{H}$ Minus Reverse Transcriptase (Thermo Scientific, Fermentas, \#EP0451), which is a genetically modified M-MuLV RT. The expression of target genes' mRNAs in the head kidney and hepatic tissue was examined using Real-time PCR with SYBR Green, with $\beta$-actin as an internal guide. Amplification of isolated cDNA was done using 2X Maxima SYBR Green/ROX qPCR Master Mix (\# K0221, Thermo scientific, USA) and genespecific primers according to manufacture's instructions. The primer pairs used in the amplification are listed in Table 1. The primer sets based on published Nile tilapia sequences and were developed using the web-based tool Primer 3 (http://www-genome.wi.mit.edu/cgi-bin/primer/primer3 www.cgi). To confirm that the primer sequence matches the template sequence exactly, we used BLAST (www.ncbi.nlm.nih.gov/blast/Blast.cgi) to compare it to other known sequences. RT-qPCR was carried out in a $25 \mu \mathrm{l}$ of $3 \mu \mathrm{l}$ cDNA template, $1 \mu \mathrm{l}$ of each Forward and reverse primer, $12.5 \mu \mathrm{l}$ of $2 \mathrm{X}$ Maxima SYBR Green and $7.5 \mu$ l nuclease free water. Step One Plus real time thermal cycler used where PCR thermal condition as follow, cDNA initial denaturation at $95^{\circ} \mathrm{C} / 10 \mathrm{~min}$, then 40 cycles of denaturation at $95^{\circ} \mathrm{C} / 15 \mathrm{sec}$, annealing $60^{\circ} \mathrm{C} / 30 \mathrm{sec}$, and extension at $72^{\circ} \mathrm{C} / 30 \mathrm{sec}$. The quantities critical threshold $(\mathrm{Ct})$ of target gene were normalized with quantities $(\mathrm{Ct})$ of housekeeping gene ( $\beta$-actin). For the test groups, assessment of fold change of relative gene expression was calculated as follow: Fold change $=(2-\Delta \Delta \mathrm{Ct})$ (Livak \& Schmittgen, 2001).

\subsection{Physicochemical properties of waters}

Water quality were monitored and sampled daily while remnants of the unconsumed feed and the excreta were also siphoned. Water quality parameters such as Temperature, $\mathrm{pH}$, Ammonia, Nitrite, Total hardness, Total alkalinity and Dissolved oxygen were monitored and estimated, following the procedure of (APHA, 2005).

Table 1: Primers sequence for MHC IIA, Tlr7, IgM heavy chain, TNF- $\alpha$, and $B$ actin used for gene expression.

\begin{tabular}{|c|c|c|}
\hline Gene & $\begin{array}{c}\text { Forward primer } \\
\left({ }^{\prime} 5 \text { - }\right.\end{array}$ & $\begin{array}{c}\text { Reverse primer } \\
\left({ }^{\prime} 5 \text { - }-y^{\prime} 3\right)\end{array}$ \\
\hline MHC IIA & CATCAAAGGAAACGAGTGCA & CTACTTTCAGCCGCTCTCCC \\
\hline Tlr7 & TCAGCAGGGTGAGAGCATAC & ACATATCCCAGCCGTAGAGG \\
\hline $\begin{array}{l}\text { IgM } \\
\text { heavy chain }\end{array}$ & AGGAGACAGGACTGGAATGCACAA & GGAGGCAGTATAGGTATCATCCTC \\
\hline$T N F-\alpha$ & GGTTAGTTGAGAAGAAATCACCTGCA & GTCGTCGCTATTCCCGCAGATCA \\
\hline B-actin & CAGCAAGCAGGAGTACGATGAG & TGTGTGGTGTGTGGTTGTTTTG \\
\hline
\end{tabular}




\subsection{Study of Histopathological Alterations}

Tissue specimens from liver and kidney were collected by sacrificing the fish. For a period of 24 hours, the tissues were held in $10 \%$ formaldehyde solution. The fixed tissues were exposed to increasing concentrations of ethanol $(30,50,70$, 90 and 100 percent) (Al-Gomhoureia Co., Egypt) to dehydrate them. The dehydrated liver samples were cleared in xylene until they became translucent. Then transferred to molten paraffin wax for $1 \mathrm{~h}$ to remove xylene completely and then embedded in wax. The embedded liver samples were sectioned at 4 to $6 \mu \mathrm{m}$ thickness. Tissue slices were adhered to clean and dry slides. Staining with haematoxylin and eosin after drying. Lastly, the liver as well as kidney slices were investigated under light optical microscope for any structural alterations and compared to the control group (Bancroft \& Gamble, 2008).

\subsection{Statistical analysis}

Means \pm S.E. were used to explain the experimental results. One-way analysis of variance (ANOVA) was used to determine the factual significance using SPSS ver. 18.0 software, 2011. and Duncan's multiple range test was used to assess the individual associations, when $\mathrm{p} \leq 0.05$ was achieved, the values were deemed statistically significant. The data were presented as mean \pm standard error of the mean (SEM), with a significance level at $\mathrm{p} \leq 0.05$.

\section{RESULTS}

\section{DNA damage detection}

DNA damage in liver of fish following exposure to OTC (G2), MAL (G3) or FMG (G4) determined by comet assay were shown in (Table 2 and Fig. 1). Exposure of fish to OTC (G2), MAL (G3) or FMG (G4) result in significant increases in DNA damage ( $\mathrm{P}<0.05)$, with highest damage in $\mathrm{G} 3$ followed by G4 then G2, as compared to control group (G1) (Table2, Fig.1). Increases in tail length, tail DNA percent, and tail moment suggested this damage.

Table 2: Parameters of comet assay obtained by image analysis in liver cells of all groups after 21 days' treatment experiment.

\begin{tabular}{cccccc}
\hline Group & Tailed \% & Untailed \% & Tails length $\boldsymbol{\mu m}$ & Tail DNA\% & Tail moment \\
\hline $\boldsymbol{G 1}$ & $2.5^{\mathrm{d}}$ & $97.5^{\mathrm{a}}$ & $1.80 \pm 0.15^{\mathrm{d}}$ & $1.52^{\mathrm{d}}$ & $2.74^{\mathrm{d}}$ \\
\hline $\boldsymbol{G} 2$ & $10^{\mathrm{c}}$ & $90^{\mathrm{b}}$ & $3.79 \pm 0.19^{\mathrm{c}}$ & $2.75^{\mathrm{c}}$ & $10.42^{\mathrm{c}}$ \\
\hline $\boldsymbol{G 3}$ & $31^{\mathrm{a}}$ & $69^{\mathrm{d}}$ & $10.48 \pm 0.71^{\mathrm{a}}$ & $8.83^{\mathrm{a}}$ & $92.54^{\mathrm{a}}$ \\
\hline $\boldsymbol{G 4}$ & $18^{\mathrm{b}}$ & $82^{\mathrm{c}}$ & $6.27 \pm 0.29^{\mathrm{b}}$ & $5.01^{\mathrm{b}}$ & $31.41^{\mathrm{b}}$
\end{tabular}

Different superscript letters in the same column of tail length showed significance difference at $\mathrm{P}<0.05$ 

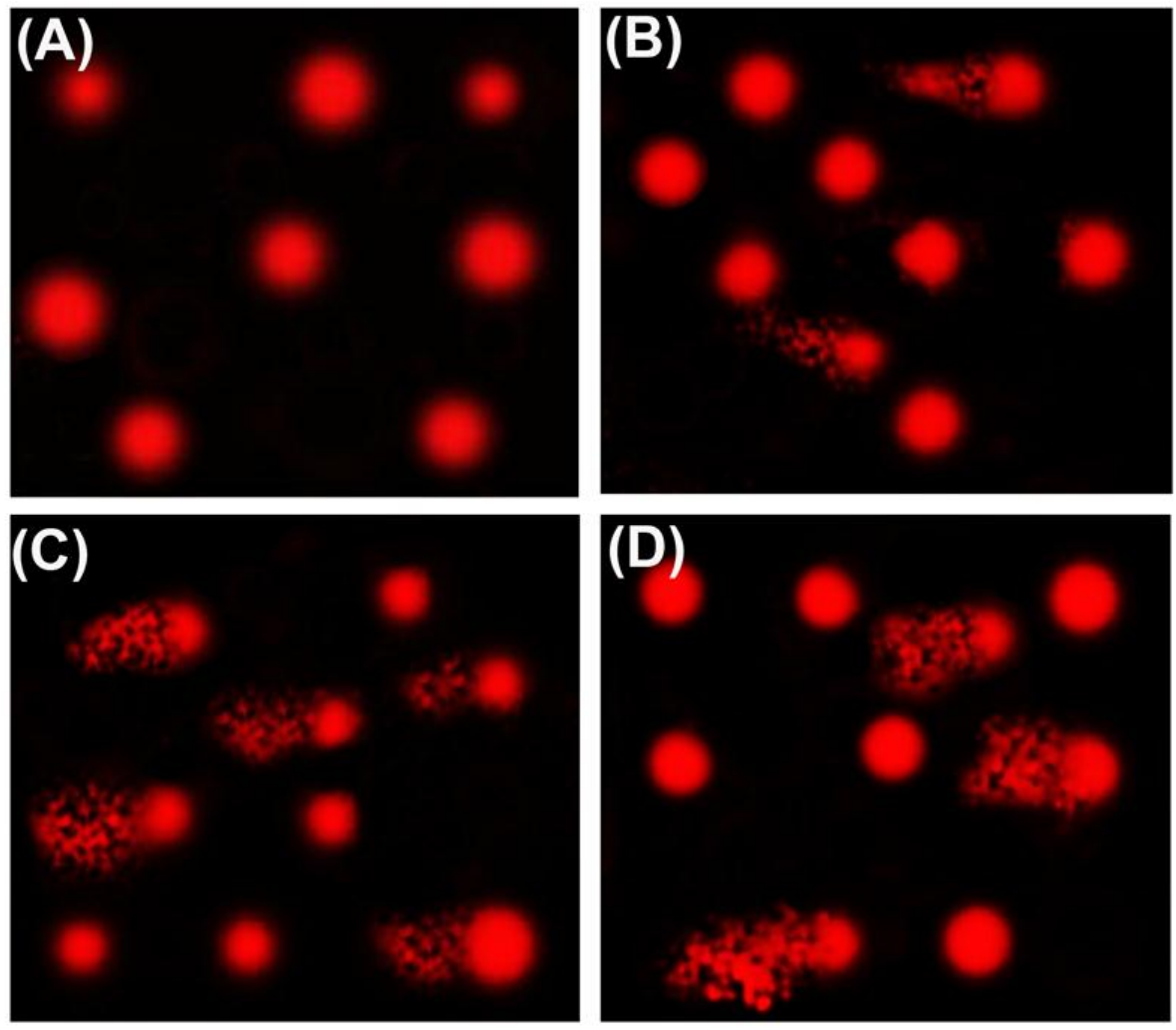

Fig.1. DNA damage photomicrographs representation in hepatic sample tissues, in control group (A), OTC(B), MAL (C), or FMG (D) following 21 days' exposure.

\section{Immune gene expression}

The obtained qPCR results showed a significant downregulation in the expression levels of the MHC IIA, IgM heavy chain, Tlr7genes (Table 3, Figs 2, 3, 4) respectively in head kidney of fish treated with OTC (G2), MAL (G3) or FMG (G4) with lowest expression in G3 followed by G4 then G2 compared to control, but significant upregulation appeared in the expression levels of the TNF- $\alpha$ gene (Table 3, Fig. 5) in the liver of fish treated with OTC (G2), MAL (G3) or FMG (G4) with highest expression in G3 followed by G4 then G2 compared to control.

Table 3: Relative expression of MHCIIA, IgM heavy chain, TLR7 in O. niloticus headkidney and TNF- $\alpha$ in liver following treatments with OTC(G2), MAL (G3) and FMG (G4) for 21 days.

\begin{tabular}{ccccc}
\hline Group & MHC IIA & IgM heavy chain & TLR7 & TNF- $\boldsymbol{\alpha}$ \\
\hline $\boldsymbol{G 1}$ & $1.00^{\mathrm{a}} \pm 0.05$ & $1.00^{\mathrm{a}} \pm 0.07$ & $1.00^{\mathrm{a}} \pm 0.05$ & $1.00^{\mathrm{d}} \pm 0.08$ \\
\hline $\boldsymbol{G} \boldsymbol{2}$ & $0.46^{\mathrm{b}} \pm 0.02$ & $0.53^{\mathrm{b}} \pm 0.04$ & $0.67^{\mathrm{b}} \pm 0.03$ & $2.55^{\mathrm{c}} \pm 0.13$ \\
\hline $\boldsymbol{G 3}$ & $0.24^{\mathrm{d}} \pm 0.01$ & $0.07^{\mathrm{d}} \pm 0.003$ & $0.19^{\mathrm{d}} \pm 0.01$ & $5.74^{\mathrm{a}} \pm 0.27$ \\
\hline $\boldsymbol{G 4}$ & $0.32^{\mathrm{c}} \pm 0.02$ & $0.31^{\mathrm{c}} \pm 0.02$ & $0.42^{\mathrm{c}} \pm 0.03$ & $3.89^{\mathrm{b}} \pm 0.21$ \\
\hline
\end{tabular}

Means within the same column carrying different superscript letters are significantly different $(\mathrm{P} \leq 0.05)$. 


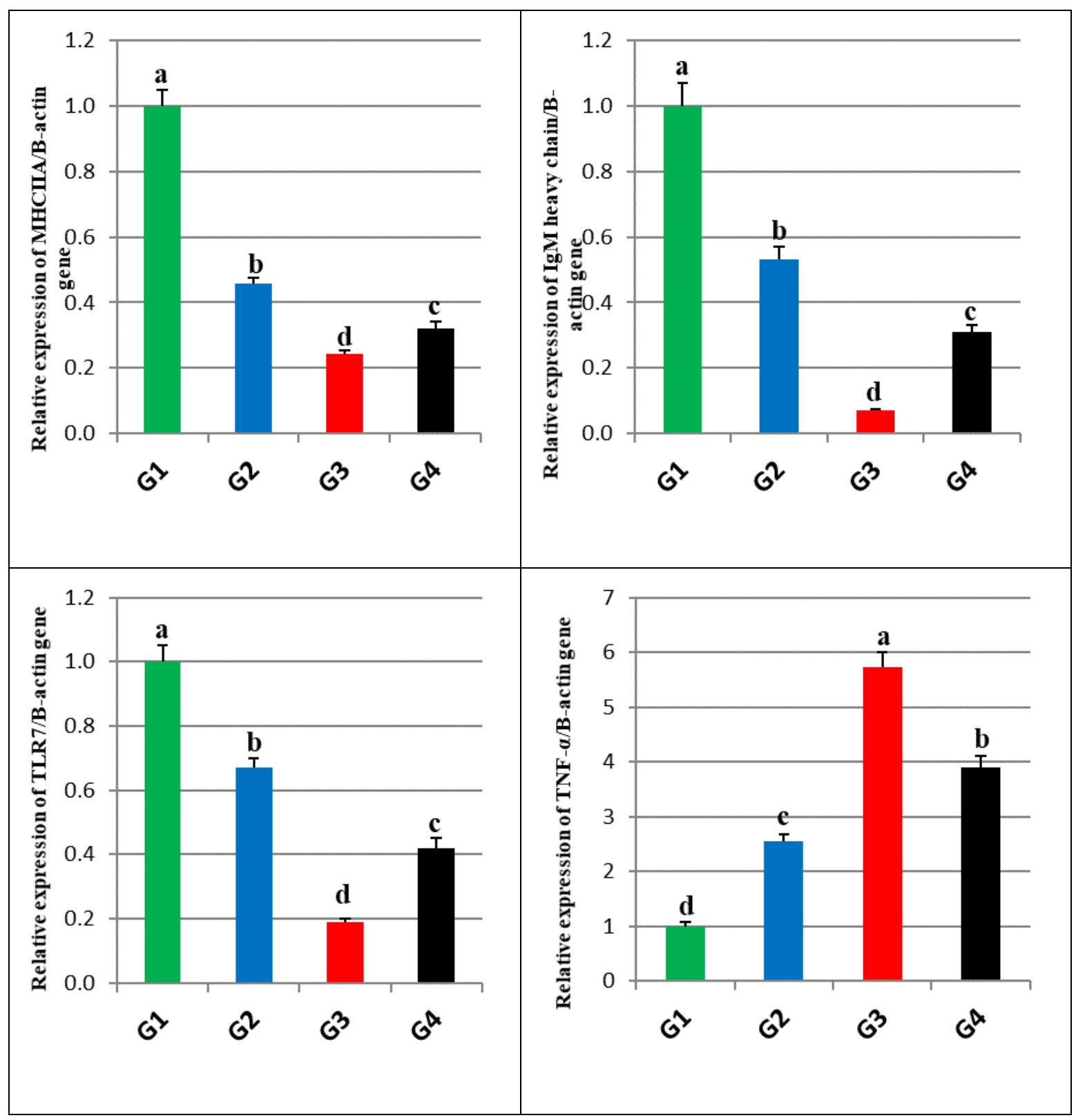

Fig. 2. Effect of OTC, MAL, or FMG on expression of $M H C I I A, I g M$ heavy chain, TLR7 genes in head-kidney and $T N F-\alpha$ gene in liver after 21 days of treatment. Data presented as mean \pm SEM $(n=7 /$ experimental group). Columns with dissimilar letters are significant. 


\section{Physicochemical Properties of Test Water}

There was no mortality in any experimental group during experimental period. The physico-chemical characteristics of the water for all the experimental periods remained constant and found to be within the limits of EOS- (1589/2005) as presented in (Table 4).

Table 4: Physico-chemical water parameters used in the experiments.

Values are shown as mean \pm SD $(n=5)$.

\begin{tabular}{|c|c|c|}
\hline Analysis & Result & $\begin{array}{c}\text { Permissible limits by } \\
\text { EOS- }(1589 / 2005)\end{array}$ \\
\hline Appearance / Color & Clear & Clear \\
\hline Odor & Odourless & Odourless \\
\hline $\mathrm{pH}$ & 7.4 & $6-7.5$ \\
\hline Temperature & 25 & $23.6-25$ \\
\hline Conductivity $(\mathrm{ms} / \mathrm{m})$ & 1520 & 2000 (Microms/m) \\
\hline Calcium(mg/l) & 80 & Up to -150 \\
\hline Calcium Carbonate(mg/l) & 200 & Up to -400 \\
\hline Magnesium(mg/l) & 24 & Up to -50 \\
\hline Magnesium Carbonate(mg/l) & 84 & Up to -175 \\
\hline Total hardness (mg/l) & 284 & Up to -500 \\
\hline $\mathrm{TSS}(\mathrm{mg} / \mathrm{l})$ & 150 & Up to -250 \\
\hline $\mathrm{TDS}(\mathrm{mg} / \mathrm{l})$ & 1110 & Up to -750 \\
\hline $\mathrm{TS}(\mathrm{mg} / \mathrm{l})$ & 1260 & Up to -1000 \\
\hline Chloride(mg/l) & 350 & $\begin{array}{l}\text { Up to }-250-\mathrm{H} \\
\text { Up to }-500-A\end{array}$ \\
\hline Ammonia(mg/l) & $-\mathrm{Ve}$ & Up to -0.5 \\
\hline Nitrite(mg/l) & $-\mathrm{Ve}$ & Up to -0.02 \\
\hline Sulphate $(\mathrm{mg} / \mathrm{l})$ & 54 & Up to -25 \\
\hline Phosphours(mg/l) & $-\mathrm{Ve}$ & No limit \\
\hline Phosphate(mg/l) & $-\mathrm{Ve}$ & Up to -5 \\
\hline Free Chlorine(mg/l) & 0.32 & $0.4-5$ \\
\hline Total alkalinity $(\mathrm{mg} / \mathrm{l})$ & 160 & Up to -100 \\
\hline Bicarbonate alkalinity $(\mathrm{mg} / \mathrm{l})$ & 160 & No limit \\
\hline Carbonate alkalinity $(\mathrm{mg} / \mathrm{l})$ & 0 & No limit \\
\hline Hydroxide alkalinity (mg/l) & 0 & No limit \\
\hline Lead(ppb) & $-\mathrm{Ve}$ & 0.01 \\
\hline Copper(ppm) & $-\mathrm{Ve}$ & 2 \\
\hline Iron(ppm) & 0.006 & \\
\hline Manganise(ppm) & $-\mathrm{Ve}$ & 0.1 \\
\hline Zinc (ppm) & $-\mathrm{Ve}$ & 3 \\
\hline Cynide test & $-\mathrm{Ve}$ & \\
\hline
\end{tabular}




\section{The results of histopathological examination}

\section{1- Liver histopathology}

Histopathologically, liver section of G1 (non- treated) control group showed intact normal pancreatic acini and blood sinusoids surrounded with intact hepatocytes (Fig.3 A). G2 (OTC treated) revealed pancreatic acini, small areas of hemorrhage, congested blood sinusoids, degeneration of pancreatic and hepatic cells in addition to severe vacuolation in hepatocytes (Fig.3 B). G3 (MALtreated) showed shrinkage, congested blood sinusoids, vacuolation and degeneration hepatocytes (Fig.3 C). On other hands, G4 (FMGtreated) showed sever effect after 21 days of exposure where, necrosis and degeneration occurred in pancreatic acini and hepatic parenchyma, lymphocytes aggregation in addition to hemorrhage and hemosiderosis (Fig.3 D).

\section{2- Kidney histopathology}

Histopathologically, kidney section of G1 (non- treated) control group showed normal-sized blood vessel, melanomacrophage center, hemopoietic tissue and lymphopoietic tissue (Fig.4 A). G2 (OTC treated) revealed blood vessel, increase in melanomacrophage center, mild increase in lymphopoietic tissue over hemopoietic tissue with presence of hemosiderosis (Fig.4 B). G3 (MAL treated) showed severe congestion of the blood vessel, degeneration in the kidney parenchyma and increase in melanomacrophage center (Fig.4 C). On other hands,G4 (FMGtreated) showed degenerative changes in the parenchymatous tissue withincrease in melanomacrophage center as shown in (Fig.4 D).

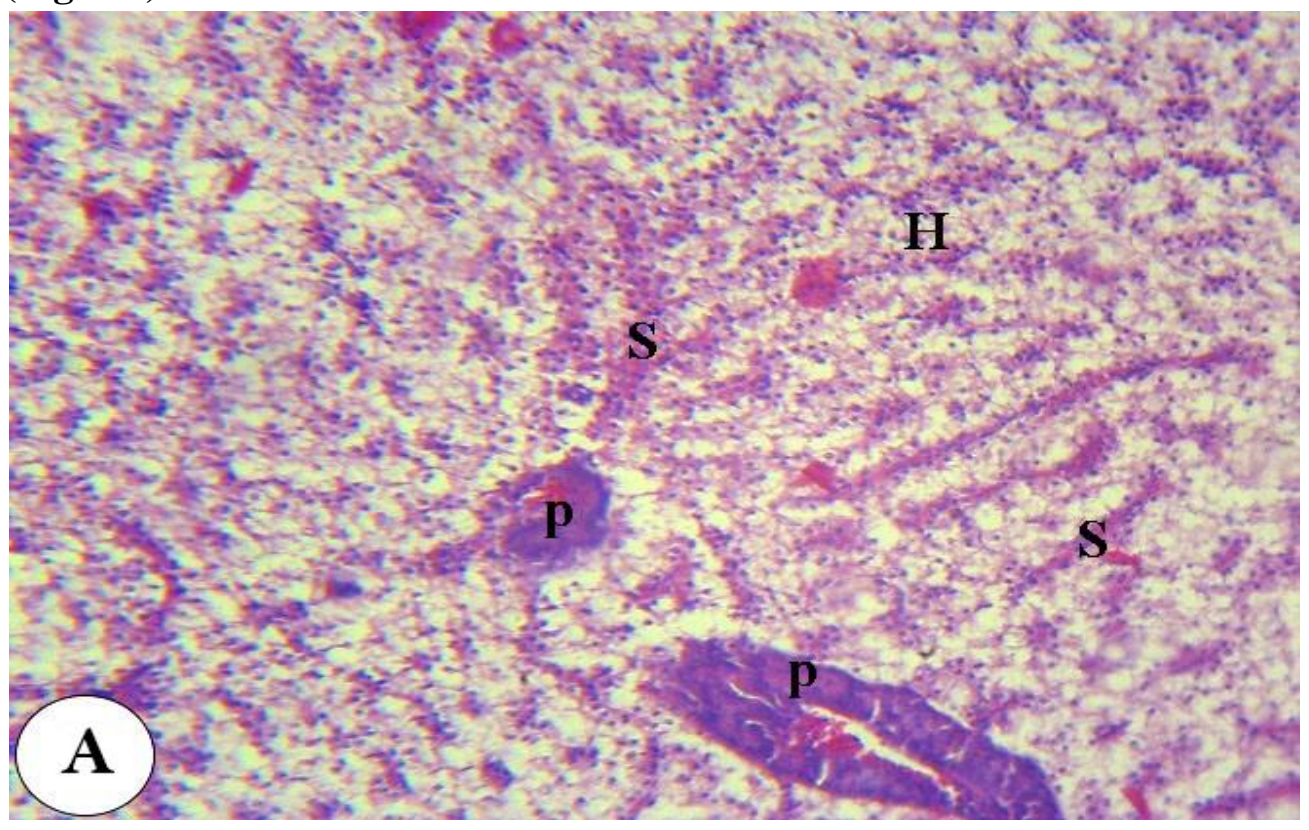

Fig. 3. A: hepatopancreas of control group showing intact normal pancreatic acini (P) and blood sinusoids (S) surrounded with intact hepatocytes $(\mathrm{H})$. H\&E, X 


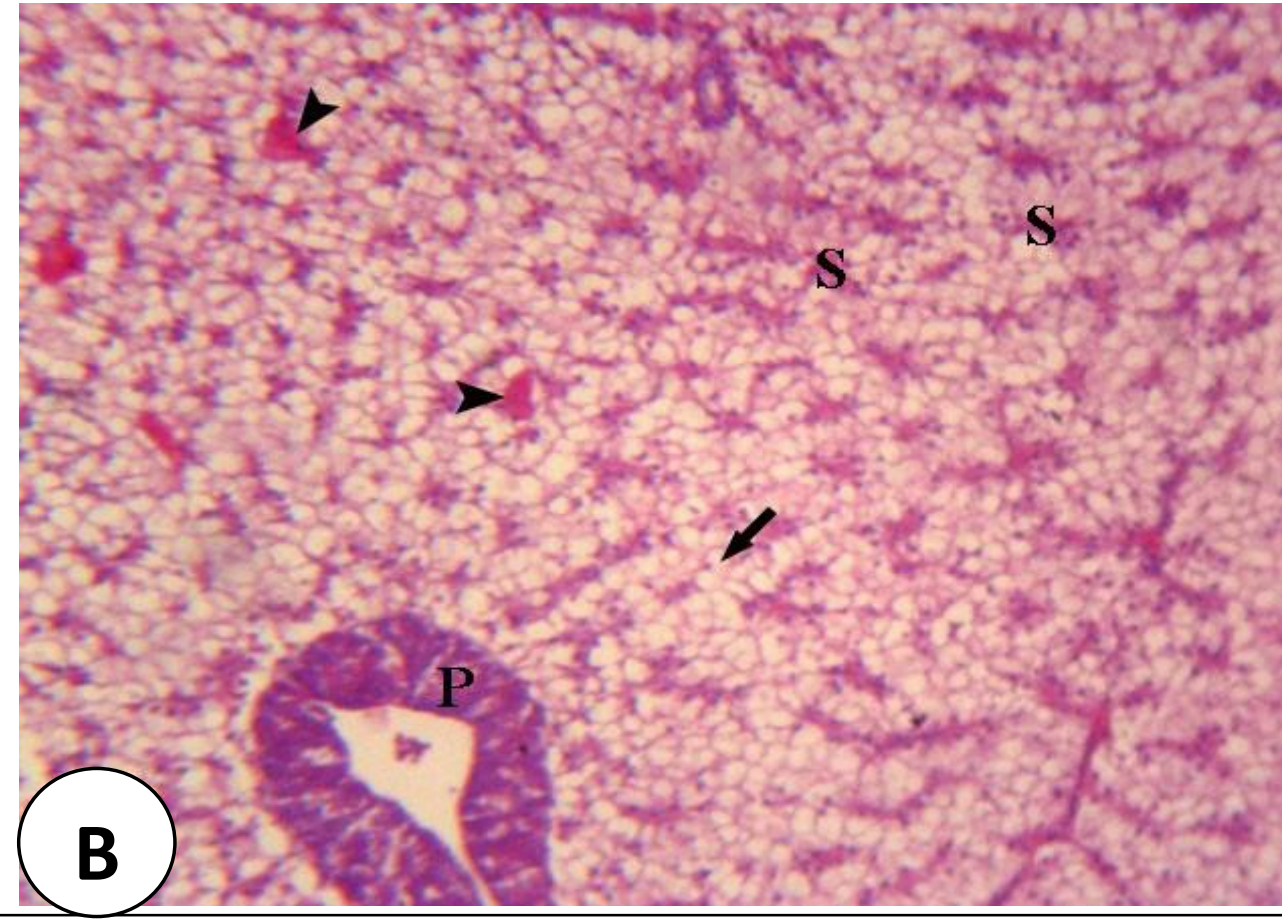

Fig. 3 (B): Hepatopancreas of OTC group after 21 days showing pancreatic acini (P), small areas of hemorrhage (arrow head), congested blood sinusoids (s) and vacuolation of hepatocytes (arrow). H\&E, X 100.

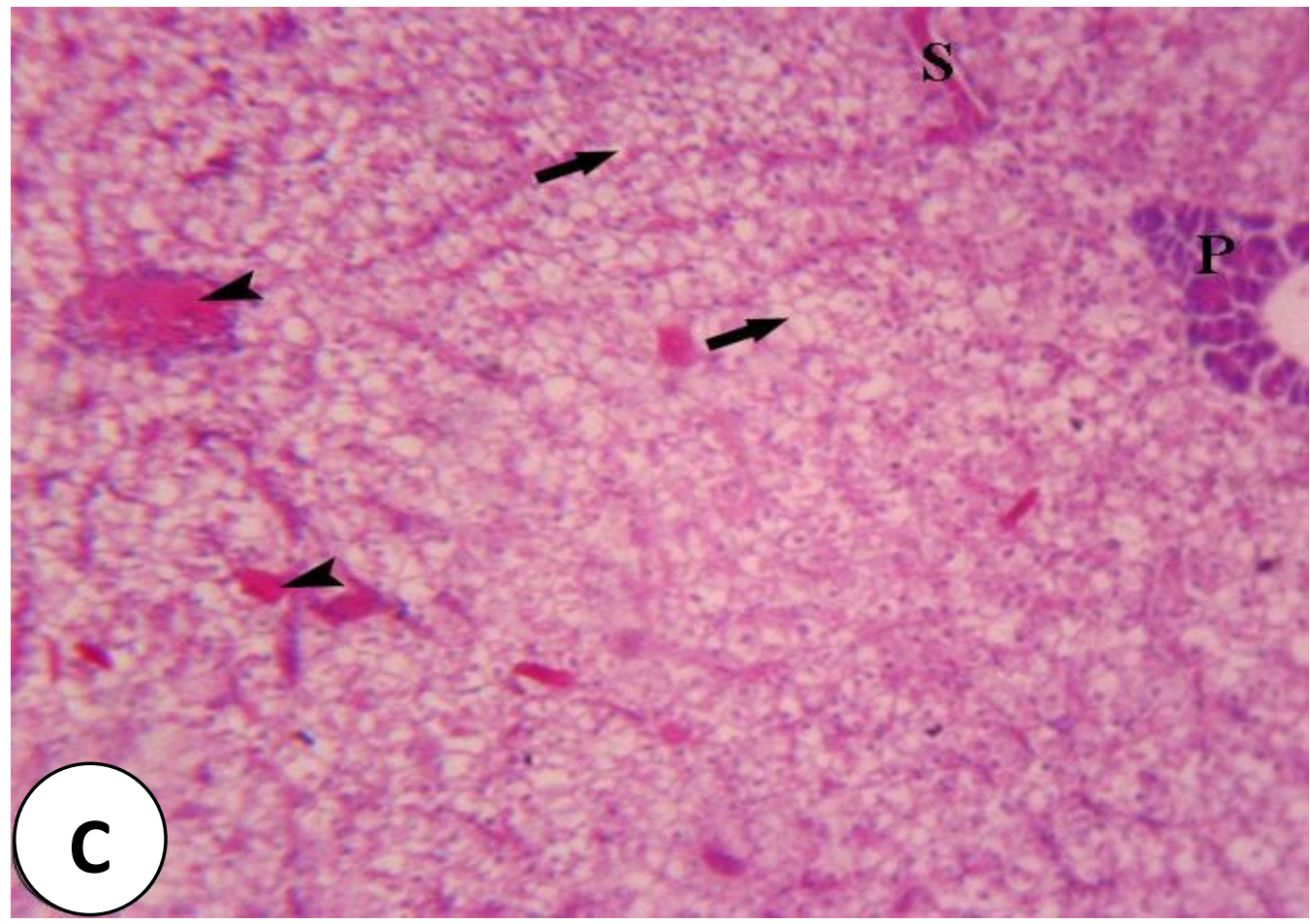

Fig. 3 (C): Hepatopancreas of MAL group after 21 days showing shrinkage of pancreatic cells $(\mathrm{P})$, congested blood sinusoids $(\mathrm{S})$, focal areas of hemorrhage (arrow head) and vacuolar degeneration of hepatocytes (arrow). H\&E, X 100. 


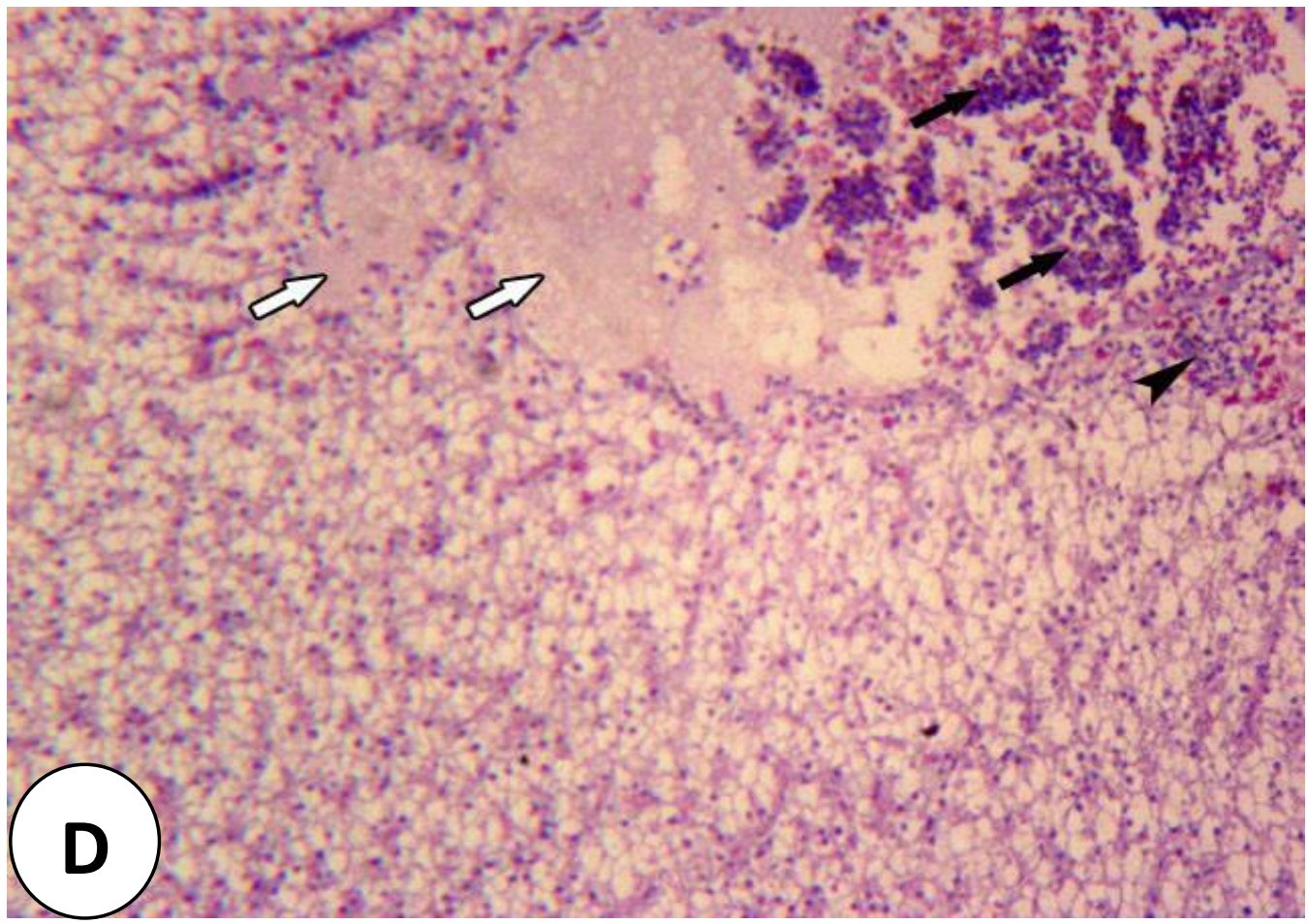

Fig. 3 (D): Hepatopancreas of FMG group after 21 days showing necrosis of pancreatic acini (black arrow) and hepatic parenchyma (white arrow) in addition to lymphocytes aggregation (arrow head). H\&E, X 100.

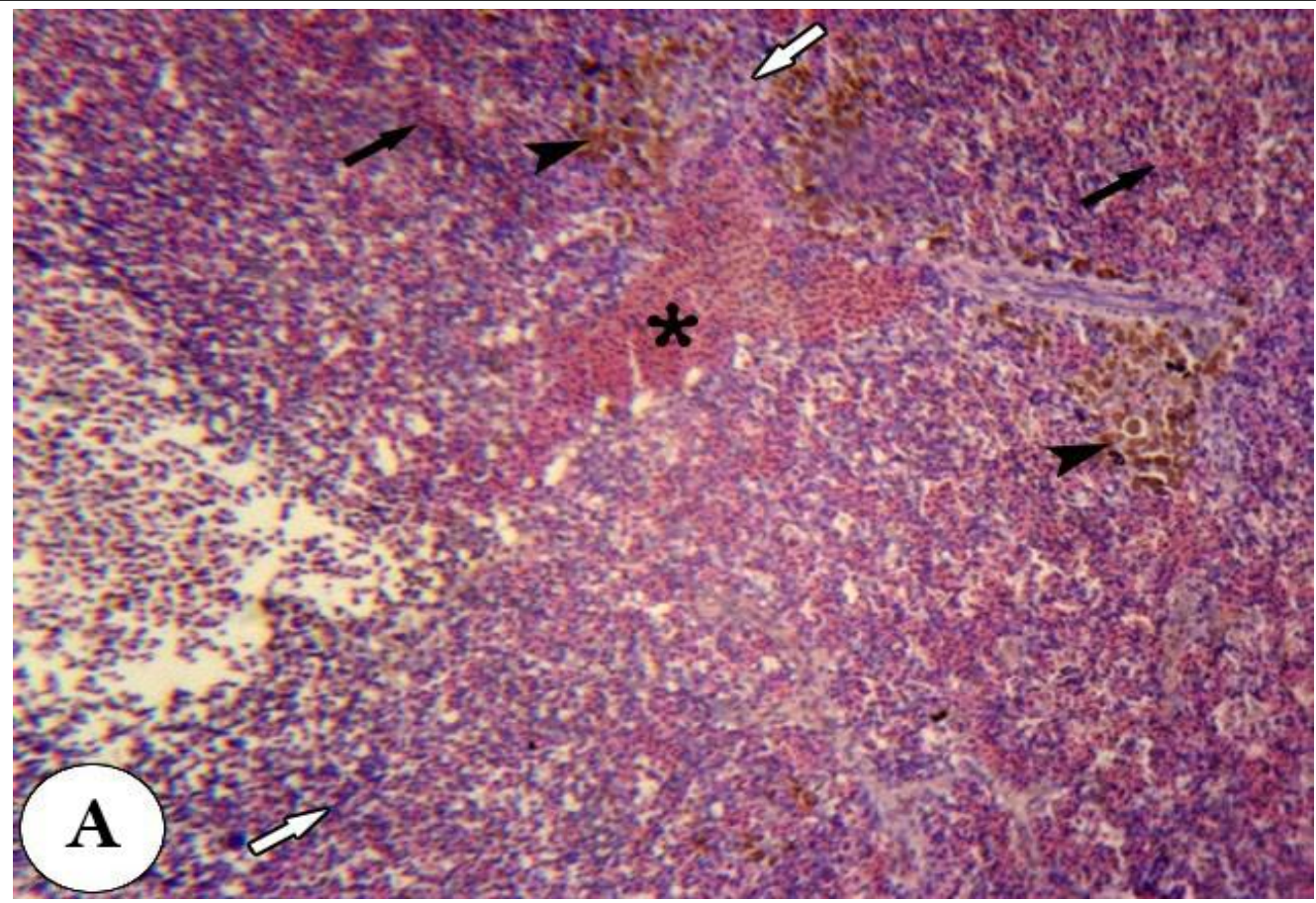

Fig. 4 (A): Anterior kidney of control group showing normal-sized blood vessel (asterisk), melanomacrophage center (arrow head), hemopoietic tissue (black arrow) and lymphopoietic tissue (white arrow). H\&E, X 100. 


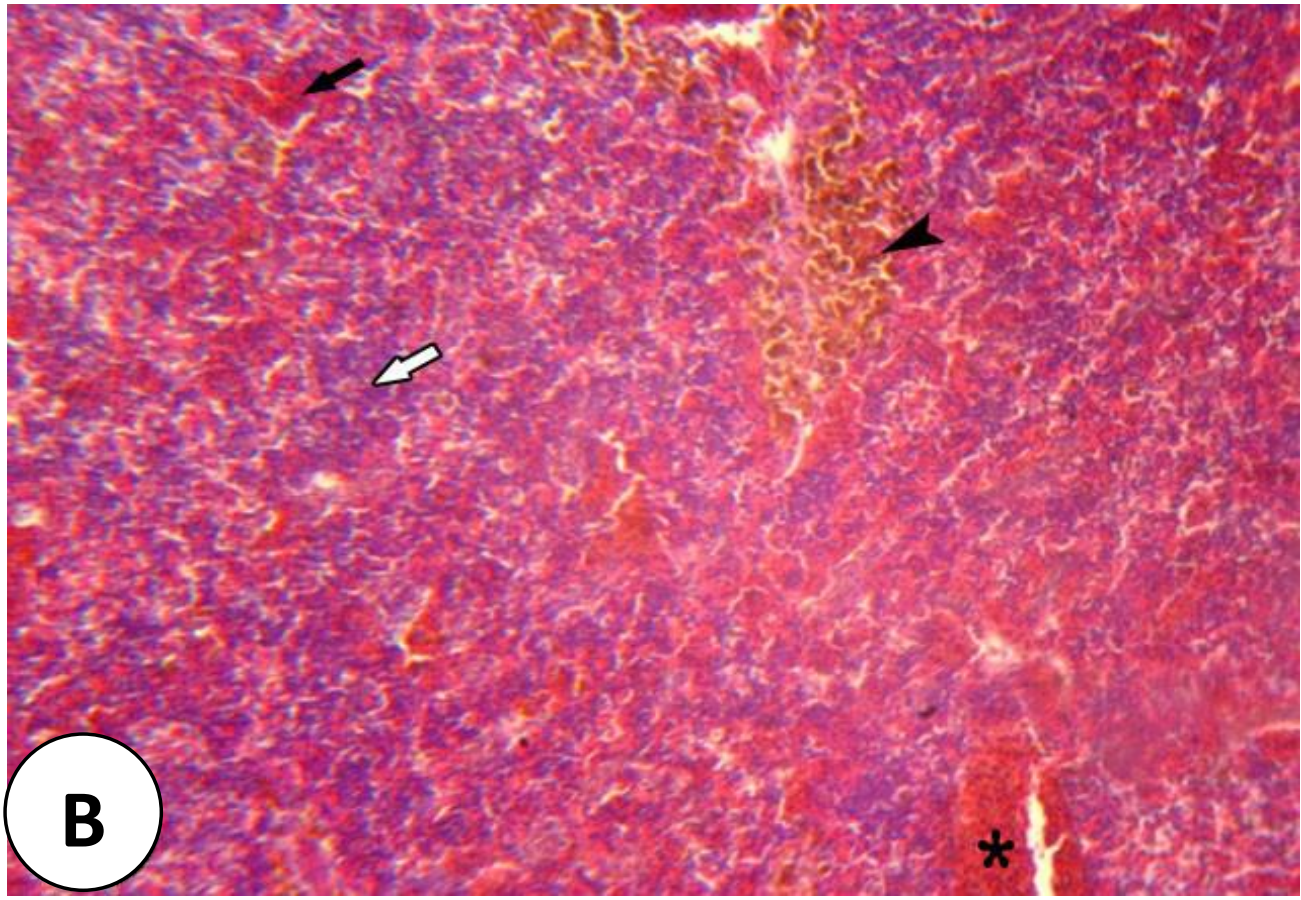

Fig. 4 (B): Anterior kidney of OTC group after 21 days showing blood vessel (asterisk), increase in melanomacrophage center (arrow head), mild increase in lymphopoietic tissue (white arrow) over hemopoietic tissue (black arrow). H\&E, X 100.

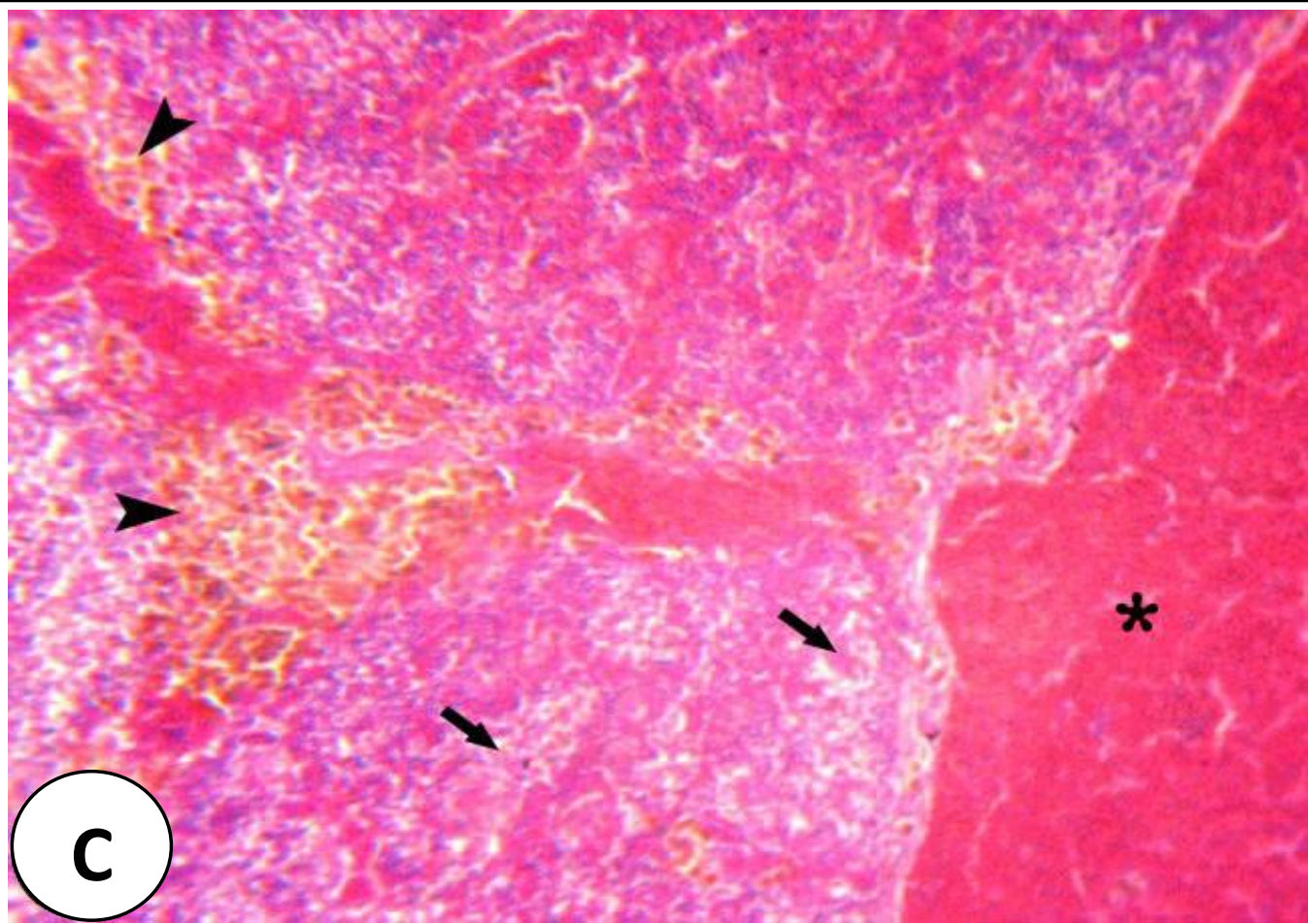

Fig. 4 (C): Anterior kidney of MAL group after 21 days showing severe congestion of the blood vessel (asterisk), degeneration in the kidney parenchyma (arrow) and increase in melanomacrophage center (arrow head). H\&E, X 100. 


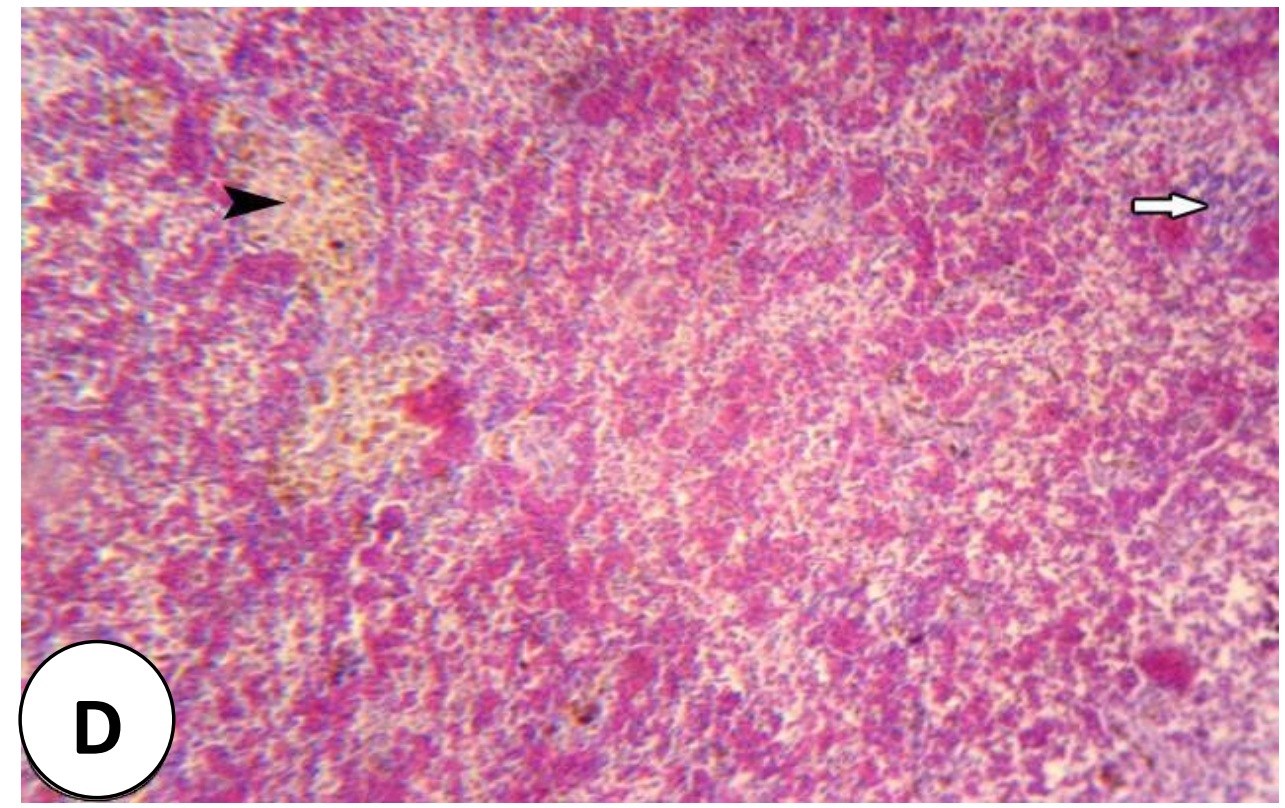

Fig. 4 (D): Anterior kidney of FMG group after 21 days showing increase in melanomacrophage center (arrow head) in addition to depletion of lymphopoietic tissue (white arrow). H\&E, X 100.

\section{DISCUSSION}

In many developing countries, aquaculture is crucial for providing food security for millions of People. It is therefore important to assess the full impact of the environmental changes on the Aquaculture sustainability. Because of over population and unintended civilization, many aquatic ecosystems are facing complicate problems of contamination (El-Adawy et al., 2018).

Pressure outbreaks of disease caused by viral, bacterial, fungal and parasitic infections or Direct emissions of micro-contaminants from fish farming facilities in seawater may result in contamination of the marine environment have led to the use of chemicals (Lulijwa, 2020). Nile tilapia (Oreochromis niloticus) is an excellent model for aquaculture, fundamental research, and environmental contamination studies so present work was planned to illustrate, the genotoxic and histopathological effect of most common applied chemicals in aquaculture as OTC from antibiotics group, MAL from pesticides group or FMG from disinfectant group. 
In the present study we found chemicals treated groups can significantly induce DNA damage of liver tissue cells indicating the genotoxic potential of this chemicals in Nile tilapia with high reference to MAL treated group. In support, similar results were reported by other studies such as (Kushwaha et al., 2000; Kumar et al., 2010), who concluded that, when teleost fish Channa punctatus (Bloch) was exposed to MAL levels, DNA damage levels increased in gill, kidney, and lymphocyte. The organ produces a number of metabolites during the detoxification process that challenge the integrity of prominent biomolecules such as proteins and DNA of liver cells and cause serious damage to DNA strands (Cajaraville et al., 2003). Similarly, Yin et al. (2008) reported that genotoxicity in RBCs and liver cells of Chinese toad (Bufo gargarizans) when exposed to the sub lethal dose of chlorpyrifos. Also triclosan elicited genotoxicity in hemocytes of zebra mussel (Hemalatha et al., 2019). Also, Gyimah et al. (2020) reported DNA damage in liver tissue of adult zebrafish after exposure to antimicrobial agent triclosan.

Other studies have also reported lead exposure causing genotoxic effects, such as chromosome aberration, mutation, inhibition of DNA synthesis and breakage of DNA (Celik et al., 2005). Abd El-satar et al. (2019) reported similar result when exposed Claries gariepinus to lead acetat and chlorpyrifose.

Relative Changes in mRNA expression levels of MHC IIA, Tlr7, IgM heavy chain, TNF- $\alpha$ were revealed in response to OTC, MAL or FMG exposure in comparison with those in the non-treated group. The obtained result indicated that MAL exposure could significantly inhibit the MHC IIA, Tlr7 and IgM heavy chain gene expression followed by FMG then OTC, reducing the immune response of $O$. niloticus resulting in increased susceptibility to infection (Blakley $\boldsymbol{e t}$ al., 1999). In line with our results Tang $\boldsymbol{e t}$ al. (2021) who found exposure of crucian carp to diazinon revealed that, the expression levels of TLR4, MyD88, NF-kB p100 and IL-8 genes were significantly reduced compared to those of the controls. In opposite the gene of mediators involved in the inflammation response as TNF-a gene, TNF- $\alpha$ is a proinflammatory cytokine involved in inflammation, apoptosis, cell proliferation, and the stimulation of various aspects of the immune system (Ma et al., 2014). qPCR results showed a significant upregulation in the expression levels of the TNF-a genein the treated chemicals liver group with highest expression in MAL exposure followed by FMG then OTC. In agree with our results Liu et al. (2018), in the inflammatory response in zebrafish after paraquat (PQ) exposure, upregulation ofIL-8 and NF-kB gene expression was found. TNF- $\alpha$ and TNF- $\beta$ are important mediators of inflammatory and immune response mechanisms. TNF- $\alpha$ and TNF- $\beta$ expression were also significantly up-regulated in 
zebrafish exposed to fluoroquinolone and tetracycline (Zhang et al., 2016); TNF- $\alpha$ activation could trigger leukocytes to express adhesion molecules on their cell surface, resulting in diapedesis through individual endothelial vascular cells (Wu \& Chen, 2014). In addition, Ma et al. (2014) reported that $P Q$ significantly increased the expression levels of TNF- $\alpha$ gene expression in the spleen (1 d) and liver (3-7 d) of crucian carp. Ryu et al. (2014) showed that exposure to Perfluorooctanoic acid (PFOA) causes a marked increase in the mRNA expression level of IFN. Wang et al. (2011) reported that following exposure to atrazine, chlorpyrifos, or a mixture of both, IL-1 $\beta$ expression was upregulated in the kidney and spleen of common carp. Zhong et al. (2020) found that after exposure to an organic pollutant (PFOA), the expression levels of both TLR-2 and MyD88 genes in zebra fish increased, implying that the immune response was influenced through the TLR/MyD88/NF-kB pathway.

Physicochemical parameters such as temperature, $\mathrm{pH}$, total dissolved solids, dissolved oxygen and electric conductivity are essential aquatic indices which determine growth, reproduction and fish health (Audu et al., 2014). All the water quality parameters measured in this study were within the Permissible limits by EOS- (1589/2005), for general fish survival and growth. Since MAL has a half-life of 0.2 weeks at $\mathrm{pH} 8.0$ and 21 weeks at $\mathrm{pH} 6.0$ (Hazardous Substances Databank, 1988), it was necessary to adjust the test water every other day with freshly prepared solution to keep the pesticide test concentration during the experiment.

In this study, MAL caused several kidney and liver lesions. While the liver is responsible for removing poisonous compounds and detoxify it, high levels of these toxic compounds cause tissue harm. Histopathological changes in the liver were similar to the organophosphate pesticide's typical histological reactions (Subburaj, 2018). Dawood et al. (2020) found the hepatotoxicity due to deltamethrine caused most hepatocytes to vacuolate, revealing pyknotic nuclei and fatty degeneration in the vacuolated hepatocytes. Ourresults are also in the same manner of the study carried out by (Muttappa $\boldsymbol{e t}$ al., 2015) who revealed histopathological changes in the liver of Nile tilapia such as necrosis, vacuolization, increase in number of kupffer cells, and aggregation of melanomacrophge after exposure to ciprofloxacin, Histopathological alterations in the experimental organs of Channa punctatus fresh water fish were observed after exposure to sublethal concentrations of MAL for 7 days, according to (Magar \& Shaikh, 2013), also reported Highly degenerative renal and collecting tubules with necrosis, shrinkage of glomeruli and renal tubules and spaces in Bowman's capsule. According to the finding of this study, Channa punctatus hepatic tissues exposed to MAL for 4 days showed degeneration of cytoplasm and vacuolization of hepatocyte. 
The current findings are analogous with previous studies showing numerous histopathological changes caused by pesticides in the livers of various fish species as, zebra fish Danio Rerio (Bhuvaneshwari et al., 2015) Channa punctata (Tabassum et al., 2016), Tilapia mossambica (Reddy, 2017) Labeo rohita (Ullah et al., 2018).

Histological examination is also applied to determine the risk effects of xenobiotics on fish (Bojarski et al., 2020). In the present study areas of hemorrhage, congested blood sinusoids, degeneration of pancreatic and hepatic cells in addition to severe vacuolation in hepatocyteshave been observed in the liver, increase in melanomacrophage center andmild increase in lymphopoietic tissue over hemopoietic tissue with presence of hemosiderosis observed in kidneyfollowing OTC exposure. In the same manner Gyimah et al. (2020), histopathological alteration in zebra fish liver after chronic exposure (6 hpf to 90 dpf) to triclosan. Islam et al. (2015) found addition of $4 \mathrm{~g} / \mathrm{kg}$ of OTC to Barbonymus gonionotus diet for 45 days displayed histopathological lesions in liver and kidney: fatty liver degeneration, hepatocytes vacuolation, and kidney lymphocyte aggregations. Therefore, because the liver is a vital organ in the metabolism and detoxification of xenobiotics, the damaging effects of OTC on the liver warrant scientific attention. Contrary to our results (Dobšíková et al., 2013), histopathological examination ofliver, gills, skin, spleen, and head kidneys of the common carp fed on OTC showed no pathological lesions.

In the current research, histological results of Nile tilapia treated with the FMG represented by detrimental effects in hepatic focal areas of hemorrhage, degenerative changes in hepatocytes and mono nuclear cells infiltration. These findings were inaccordance with the experimental studies conducted by Mert $\boldsymbol{e t} \boldsymbol{a l}$. (2015) who postulated that Nile tilapia liver exhibited hyperaemia, hydropic degeneration and cloudy swelling, after exposure to formalin. (El-Neweshy \& Abou Srag, 2011) found hydropic degeneration of the hepatic cells, cellular swelling of renal tubular and hemopoietic tissue necrosis after chronic malachite green toxicity in Nile tilapia, (Adeyemo \& Akano, 2012) observed multifocal necrosis of hepatocytes in the liver after 3 days of exposure to $37 \mathrm{mg} \mathrm{L}^{-1}$ formalin for 30 minutes per treatment. Malachite green affects mitochondria and causes nuclear defects in the liver, causing sinusoidal congestion and focal necrosis (Gerundo et al., 1991). Following malachite green therapy, hepatocytes of Heteropneustes fossilis showed vacuolisation and hypertrophy, followed by necrosis and cirrhosis (Srivastava et al., 1998). Nouh \& Selim (2013), intertubular capillary congestion, perivascular oedema, and tubular nephrosis were discovered when $O$. niloticus was exposed to $25.0 \mathrm{mg} / \mathrm{L}$ formalin, it developed a focal loss of haematopoietic tissueand vacuolization in the renal epithelium. 
From our result, liver and kidney tissue damages were clearer in the all chemicals treated groups. In response to different chemicals, a number of histological changes in the liver have been observed in some studies (Rafieepour $\boldsymbol{e t}$ al., 2020; Tang et al., 2021).

\section{CONCLUSION}

This study showed that even in small doses, MAL has a stronger toxic effect than OTC or FMG so we recommend that major principles underlying strategies to improve the efficiency and effectiveness of fish culture control should be followed, with efforts focused on issues that pose the greatest risk. The government must lay down requirements for fish culture safety and ensure that the requirements are through a range of regulatory measures.

\section{REFERENCES}

Abd El-satar, S.S.; Nasr, N.E.; Khailo, K.A. and Sayour, H. (2019). Hemotoxic and genotoxic effects of lead acetate and chlorpyrifose on freshwater cat fish (Calarias gariepinus). Slov Vet Res, 56: 681-1.

Abdel-Daim, M.M.; Eissa, I.A.; Abdeen, A.; Abdel-Latif, H.M.; Ismail, M.; Dawood, M.A. and Hassan, A.M. (2019). Lycopene and resveratrol ameliorate zinc oxide nanoparticles-induced oxidative stress in Nile tilapia, Oreochromis niloticus. Environmental Toxicology and Pharmacology, 69: 44-50.

Adeyemo, O.K. and Akano, O.F. (2012). Effect of Formalin on Spavvning Success and Organ Histology in Clarias gariepinus. Internet J. Hematol, 5(2).

Ahmed, A.; Abdullah, S.R.S.; Hasan, H.A.; Othman, A.R. and Ismail, N.I. (2021). Aquaculture industry: Supply and demand, best practices, effluent and its current issues and treatment technology. Journal of Environmental Management, 287:112271.

Andem, A.B.; Esenowo, I.K.; Ibor, O.R. and Abosi, A. (2015). Toxicological effects of formaldehyde concentrations on African Cat fish, Clarias gariepinus fingerlings. International Journal of Fisheries and Aquatic Studies, 2(5): 75 - 79.

APHA (American Public Health Association) (2005). Standard methods for the examination of water and waste water21 $1^{\text {st }}, 401$ Edn. American Public Health Association, American Water Works Association and Water Environmental Federation, Washington (DC).

Audu, B.S.; Adamu, K.M. and Nonyelu, O.N. (2014). Changes in haematological parameters of Clarias gariepinus exposed to century plant (Agave Americana) leaf dust. International Journal of Applied Biological Research, 6: 54-65. 
Badawy, A.A.; El-Magd, M.A. and AlSadrah, S.A. (2018). Therapeutic Effect of Camel Milk and Its Exosomes on MCF7 Cells in Vitro and in Vivo, Integrative Cancer Therapies, 7(4): 1235-46.

Bancroft, J.D. and Gamble, M. (2008). Theory and practice of histological technique ( $6^{\text {th }}$ ed.) N.Y. Churdchill Livingstone.

Bhuvaneshwari, R.; Padmanaban, K. and Babu Rajendran, R. (2015). Histopathological alterations in muscle, liver and gill tissues of zebra fish Danio rerio due to environmentally relevant concentrations of organochlorine pesticides (OCPs) and heavy metals. International Journal of Environmental Research, 9(4): 1365-1372.

Blakley, B.; Brousseau, P.; Fournier, M. and Voccia, I. (1999). Immunotoxicity of pesticides: a review. Toxicology and industrial health, 15(1-2): 119-132.

Bojarski, B.; Kot, B. and Witeska, M. (2020). Antibacterials in aquatic environment and their toxicity to fish. Pharmaceuticals, 13(8): 189.

Burgos-Aceves, M.A.; Cohen, A.; Smith, Y. and Faggio, C. (2018). MicroRNAs and their role on fish oxidative stress during xenobiotic environmental exposures. Ecotoxicology and Environmental Safety, 148: 995-1000.

Cajaraville, M.P.; Cancio, I.; Ibabe, A. and Orbea, A. (2003). Peroxisome proliferation as a biomarker in environmental pollution assessment. Microscopy Research and Technique, 61(2): 191-202.

Celik, A.; Öğenler, O. and Çömelekoğlu, Ü. (2005). The evaluation of micronucleus frequency by acridine orange fluorescent staining in peripheral blood of rats treated with lead acetate. Mutagenesis, 20(6): 411-415.

Dawood, M.A.; AbdEl-Kader, M.F.; Moustafa, E.M.; Gewaily, M.S. and Abdo, S.E. (2020). Growth performance and hemato-immunological responses of Nile tilapia (Oreochromis niloticus) exposed to deltamethrin and fed immunobiotics. Environmental Science and Pollution Research, 1-10.

Dobšíková, R.; Blahová, J.; Mikulíková, I.; Modrá, H.; Prášková, E.; Svobodová, Z. ... and Siwicki, A.K. (2013). The effect of oyster mushroom $\beta$-1.3/1.6-D-glucan and oxytetracycline antibiotic on biometrical, haematological, biochemical, and immunological indices, and histopathological changes in common carp (Cyprinus carpio L.). Fish and shellfish immunology, 35(6): 1813-1823.

DoF, (2002). Compendium on Fish Fortnight. 10-24 August 2002, Department of Fisheries, Matsha Bhaban, Dhaka. 44-45. 
Dogan, A.; Płotka-Wasylka, J.; Kempi` nska-Kupczyk, D.; Namie’'snik, J. and KotWasik, A. (2020). Detection, identification and determination of chiral pharmaceutical residues in wastewater. Problems and challenges. TrAC Trends Anal. Chem., 122: 115710.

El-Adawy, M.; Abd El-Aziz, M.; El-Shazly, K.; Ali, N.G. and El-Magd, M.A. (2018). Dietary propionic acid enhances antibacterial and immunomodulatory effects of oxytetracycline on Nile tilapia, Oreochromis niloticus. Environmental Science and Pollution Research, 25(34): 34200-34211.

El-Neweshy, M.S. and Abou Srag, M.A. (2011). Chronic malachite green toxicity in Nile tilapia. Pathological and hematological studies with special reference to quantitative histopathological assessment. Researcher. 3(4): 55-64.

FAO (2010). "The State of World Fisheries and Aquaculture (2010)" FAO Fisheries and Aquaculture Department, Food and Agriculture Organization, Rome.

FAO (2012). State of world fisheries and aquaculture. in. Department, F.F.a.A. (Ed.), Rome. 230 pp.

FAO (2014). The State of World Fisheries and Aquaculture. Food Agricultural Organization United Nations, Rome.

Gafrd (2017). Egyptian Fish statistics year book, 2015 (27 ed.). Cairo, Egypt, General Authority for Fish Resources Development.

Gerundo, N.; Alderman, D. J.; Clifton-Hadley, R. S. and Feist, S. W. (1991). Pathological effects of repeated doses of malachite green: a preliminary study. Journal of Fish Diseases, 14(5): 521-532.

Gyimah, E.; Dong, X.; Qiu, W.; Zhang, Z.; and Xu, H. (2020). Sublethal concentrations of triclosan elicited oxidative stress, DNA damage, and histological alterations in the liver and brain of adult zebrafish. Environmental Science and Pollution Research, 1-10.

Hazardous substances databank (1988). Toxicology data network. US National Library of Medicine, Bethesda, MD.

Hemalatha, D.; Rangasamy, B.; Nataraj, B. and Ramesh, M. (2019). Assessment of triclosan impact on enzymatic biomarkers in an Indian major carp, Catla catla. The Journal of Basic and Applied Zoology, 80(1): 1-8.

Ibrahim, A.T. (2019). Biochemical and histopathological response of Oreochromis niloticus to malathion hepatotoxicity. J. Royal. Sci, 1(1): 10-15.

Islam, M.J.; Rasul, M.G.; Kashem, M.A.; Hossain, M.M.; Liza, A.A.; Sayeed, M.A. and Hossain, M.M. (2015). Effect of Oxytetracycline on Thai Silver Barb 
(Barbonymus gonionotus) and on its Culture Environment. Journal of Fisheries and Aquatic Science, 10(5): 323.

Julinta, R.B.; Abraham, T.J.; Roy, A.; Singha, J.; Dash, G.; Mali, P. ... and Kumar, K. A. (2019). Effect of Oxytetracycline-Dosing on the Growth, Safety and Intestinal Histology of Nile Tilapia, Oreochromis niloticus (L.) Juveniles. Int. J. Curr. Microbiol. App. Sci, 8(8): 2708-2724.

Kumar, R.; Nagpure, N.S.; Kushwaha, B.; Srivastava, S.K. and Lakra, W.S. (2010). Investigation of the genotoxicity of malathion to freshwater teleost fish Channa punctatus (Bloch) using the micronucleus test and comet assay. Archives of environmental contamination and toxicology, 58(1): 123-130.

Kushwaha, B.; Srivastava, S.K.; Singh, B.; Nagpure, N.S. and Ponniah, A.G. (2000). Evaluation of comet assay and micronuclei test as genotoxic assay in Channa punctatus. Natl. Acad. Sci. Lett. 23: 177-179.

Leal, J.F.; Neves, M.G.; Santos, E.B. and Esteves, V.I. (2018). Use of formalin in intensive aquaculture. properties, application and effects on fish and water quality. Reviews in Aquaculture, 10(2): 281-295.

Liu, H.; Wu, Q.; Chu, T.; Mo, Y.; Cai, S.; Chen, M.; and Zhu, G. (2018). High-dose acute exposure of paraquat induces injuries of swim bladder, gastrointestinal tract and liver via neutrophil-mediated ROS in zebrafish and their relevance for human health risk assessment. Chemosphere, 205: 662-673.

Liu, X.; Steele, J.C. and Meng, X.Z. (2017). Usage, residue, and human health risk of antibiotics in Chinese aquaculture. A review. J. Environmental Pollution, 223: 161169.

Livak, K.J. and Schmittgen, T.D. (2001). Analysis of relative gene expression data using real-time quantitative PCR and the 2- $\Delta \Delta \mathrm{CT}$ method. methods, 25(4): 402408.

Lulijwa, R.; Rupia, E.J. and Alfaro, A.C. (2020). Antibiotic use in aquaculture, policies and regulation, health and environmental risks: a review of the top 15 major producers. Reviews in Aquaculture, 12(2): 640-663.

Ma, J.; Li, X.; Li, Y.; Li, Y. and Niu, D. (2014). Toxic effects of paraquat on cytokine expression in common carp, Cyprinus carpio L. Journal of biochemical and molecular toxicology, 28(11): 501-509.

Magar, R.S and Shaikh, A. (2013). Effect of malathion toxicity on detoxifying organ of fresh water fish channa punctatus. International Journal of Pharmaceutical, Chemical and Biological Sciences, 3(3). 
Mert, R.; Caglan, A.; Benli, K. and Arslan, G. (2015). Determination of histological and genotoxic effects of formalin on Nile tilapia (Oreochromis niloticus L.). Aquaculture Research, 46: 2798-2807.

Muttappa, K. (2015). Haematological and Histological Changes in Tilapia (Oreochromis Mossambicus) Exposed to Cadmium and Chlorpyrifos (Doctoral dissertation, Karnataka Veterinary, Animal and Fisheries Sciences University, Bidar).

Nasser, N.; Babikian, J.; Monzer, S. and Saoud, I.P. (2017). Toxicity of four chemotherapeutic agents to rabbitfish Siganus rivulatus. Journal of the World Aquaculture Society, 48(6): 877-886.

Nouh, W.G., and Selim, A.G. (2013). Toxopathological studies on the effect of formalin and copper sulphate in tilapia as a commonly used disinfectant in aquaculture. Journal of Applied Environmental and Biological Sciences, 3(6): 7-20.

Rafieepour, A.; Hajirezaee, S. and Rahimi, R. (2020). Moderating effects of dietary oregano extract (Origanum vulgare) on the toxicity induced by J. Tang, W. Wang, Y. Jiang et al. Environmental Pollution xxx (xxxx) xxx 10organophosphate pesticide, diazinon in rainbow trout, Oncorhynchus mykiss: metabolic hormones, histology and growth parameters. Turk. J. Fish. Aquat. Sci. 20 https://doi.org/10.4194/1303-2712-v20_3_05.

Reddy, P.B. (2017). Evaluation of malathion induced oxidative stress in Tilapia mossambica. Trend in Fisheries Research, 6: 2319-4758.

Ren, X.; Wang, Z.; Gao, B.; Liu, P. and Li, J. (2017). Toxic responses of swimming crab (Portunus trituberculatus) larvae exposed to environmentally realistic concentrations of oxytetracycline. Chemosphere, 173: 563-571.

Rosa, J.; Lemos, M.F.L.; Crespo, D.; Nunes, M.; Freitas, A.; Ramos, F.; ..... and Leston, S. (2020). Integrated multitrophic aquaculture systems - Potential risks for food safety, Trends in Food Science and Technology, 96: 79-90.doi. https.//doi.org/10.1016/j.tifs.2019.12.008.

Ryu, M.H.; Jha, A.; Ojo, O.O.; Mahood, T. H.; Basu, S.; Detillieux, K.A. ... and Halayko, A.J. (2014). Chronic exposure to perfluorinated compounds: Impact on airway hyperresponsiveness and inflammation. American Journal of PhysiologyLung Cellular and Molecular Physiology, 307(10): L765-L774.

Salih, M.A.A.; Elinor, T.E. and Mohamed, A.H. (2017). Evaluation of low cost cage construction materials inel-Rahad Lake northern Kordofan - Sudan. International Journal of Fisheries and Aquatic Studies, 5(1): 108-111. 
Shaalan, M., El-Mahdy, M., Saleh, M. and El-Matbouli, M. (2018). Aquaculture in Egypt: insights on the current trends and future perspectives for sustainable development. Reviews in Fisheries Science \& Aquaculture, 26(1): 99-110.

Shaheen, A.; Seisay, M. and Nouala, S. (2013). An industry assessment of Tilapia farming in Egypt. African Union, International Bureau for Animal Resources (AUIBAR).

Sharma, M. (2021). Toxic Effect of Pharmaceuticals with Reference to Oxytetracycline. Asian J Pharm Clin Res, 14(1): 64-68.

Singh, N.P.; McCoy, M.T.; Tice, R.R.; and Schneider, E.L. (1988). A simple technique for quantitation of low levels of DNA damage in individual cells. Experimental cell research, 175(1): 184-191.

Srivastava, S.J.; Singh, N.D.; Sinha, R. and Srivastava, A.K. (1998). Malachite green induced histopathological lesions in the liver of a freshwater catfish, Heteropneustes fossilis (Bloch). Journal of Advanced Zoology, 19(1): 46-49.

Stephen, W. and Hanne, I. (2013). Modes of action of three disinfectant active substances. A review Regulatory Toxicology and Pharmacology, 67: 456-467.

Subburaj, A.; Jawahar, P.; Jayakumar, N.; Srinivasan, A. and Ahilan, B. (2018). Acute toxicity bioassay of Malathion (EC 50\%) on the fish, Oreochromis mossambicus (Tilapia) and associated histological alterations in gills. Journal of entomology and zoology studies, 6(1): 103-107.

Sudova, E.; Machova1, J.; Svobodova, Z. and Vesely, T. (2007). Negative effects of malachite green and possibilities of its replacement in the treatment of fish eggs and fish. a review.Veterinarni Medicina, 52(12): 527-539.

Tabassum, H.; Khan, J.; Salman, M.; Raisuddin, S. and Parvez, S. (2016). Propiconazole induced toxicological alterations in brain of freshwater fish Channa punctata Bloch. Ecological Indicators, 62: 242-248.

Tang, J.; Wang, W.; Jiang, Y.; and Chu, W. (2021). Diazinon exposure produces histological damage, oxidative stress, immune disorders and gut microbiota dysbiosis in crucian carp (Carassius auratus gibelio). Environmental Pollution, 269: 116129.

Uikey, S. (2015). Effect of malathion toxicity on fresh water fish labeo rohita. International Journal of Applied and Universal Research 2(4): 10-15.

Ullah, S.; Li, Z.; Hasan, Z.; Khan, S.U. and Fahad S. (2018). Malathion induced oxidative stress leads to histopathological and biochemical toxicity in the liver of rohu (Labeo rohita, Hamilton) at acute concentration. Ecotoxicol. Environ. Safety, 161: 270-280. 
Van Doan, H..; Hoseinifar, S.H..; Chitmanat, C..; Jaturasitha, S..; Paolucci, M..; Ashouri, G..; ... and Esteban, M. Á. (2019). The effects of Thai ginseng, Boesenbergia rotunda powder on mucosal and serum immunity, disease resistance, and growth performance of Nile tilapia (Oreochromis niloticus) fingerlings. Aquaculture, 513: 734388.

Wang, X.; Xing, H.; Li, X.; Xu, S. and Wang, X. (2011). Effects of atrazine and chlorpyrifos on the mRNA levels of IL-1 and IFN- $\gamma 2 b$ in immune organs of common carp. Fish and shellfish immunology, 31(1): 126-133.

Wu, Y.S. and Chen, S.N. (2014). Apoptotic cell: linkage of inflammation and wound healing. Frontiers in pharmacology, 5: 1.

Yi, X.Z.; Lin, C.H.; Ong, E. J.L.; Wang, M. and Zhou, Z. (2019). Occurrence and distribution of trace levels of antibiotics in surface waters and soils driven by nonpoint source pollution and anthropogenic pressure. Chemosphere, 216: 213-223.

Yin, J.; Heo, S.I. and Wang, M.H. (2008). Antioxidant and antidiabetic activities of extracts from Cirsium japonicum roots. Nutrition research and practice, 2(4): 247.

Zhang, Y.; Liu, H.; Yao, J.; Huang, Y.; Qin, S.; Sun, Z.; ... and Ke, Y. (2016). Manipulating the air-filled zebrafish swim bladder as a neutrophilic inflammation model for acute lung injury. Cell death and disease, 7(11): e2470-e2470.

Zhong, Y.; Shen, L.; Ye, X.; Zhou, D.; He, Y. and Zhang, H. (2020). Mechanism of immunosuppression in zebrafish (Danio rerio) spleen induced by environmentally relevant concentrations of perfluorooctanoic acid. Chemosphere, 249: 126-200.

Zulfiqar, A.; Yasmeen, R. and Ijaz, S. (2020). effect of malathion on blood biochemical parameters (urea and creatinine) in Nile tilapia (Oreochromis niloticus). Pakistan Journal of Science, 72 (1): 37. 